\title{
Hello, Goodbye: Closing Thoughts on Ten Years as Editor-in-Chief
}

\section{Erin L. Dolan*}

Department of Biochemistry and Molecular Biology, University of Georgia, Athens, GA 30602

\section{Dear Readers:}

It is difficult to believe that it been 10 years since I had the honor of becoming editorin-chief of CBE-Life Sciences Education. It has been a privilege to be a part of the journal's growth. And the journal has grown! In 2010, the typical LSE issue featured about a dozen papers. Now, LSE publishes almost 100 papers per year, and more in years that include a special or themed issue. The journal has been indexed for almost a decade and has a 5-year impact factor that rivals respected science education journals and surpasses leading discipline-based education research journals. Thanks to the energy and creativity of its editorial board members, LSE has innovated to meet the changing needs of its readers and authors. Features that have been added in recent years include several that aim to build capacity for high-quality research and evaluation in the biology education community, including Research Methods essays, the Online with LSE webinar series, and Anatomy of an Education Study. More and more studies published in LSE have moved beyond documenting impacts to offering mechanistic insights into biology teaching, learning, and student development.

It is even more difficult to put into words all that I have learned and how much I appreciate the contributions of people who played a critical role in fostering the growth, development, and success of the journal. LSE's success is due to many stakeholders in the biology education community, including readers, authors, and editorial board members, as well as the behind-the-scenes support from the journal's publisher, American Society for Cell Biology (ASCB), and its staff members, Eric Baker, Thea Clarke, and Mark Leader. I have been able to stand on the shoulders of giants: Sam Ward, who-along with other leaders in the ASCB community-firmly believed there should be a place for biologists to share scholarship related to teaching and learning; Sarah Elgin and Malcolm Campbell, who brought visibility and stability to the journal and grew its reach and impact; and William Wood, who continued the journal's positive trajectory. Along the way, ASCB leadership, including its executive directors and council, continued to support the journal based on the belief that biology education research offers value to the scientific community, both within and beyond cell biology.

Over the past decade, I have grown to admire and deeply value the role of professional societies in publishing. I have always been heartened by my experience with ASCB journal editorial boards, whom I truly believe are trying to do right by colleagues who are submitting their work for peer review and publication. Many times in my years as editor, I received thank you notes from authors-even authors of manuscripts that were declined-to express their appreciation for rapid and developmental feedback offered by LSE reviewers. Even more importantly, the journal has remained open access, thanks to ASCB and its editorial partner Genetics Society of America and two decades of investment by the Howard Hughes Medical Institute. Three years ago, ASCB made the difficult decision to institute article charges. This was a critical step to ensuring the long-term sustainability of the journal given the very real costs associated with publishing-from the infrastructure for managing peer review to the work involved in copyediting. This change was coupled to a firm commitment to continuing
CBE Life Sci Educ March 1, 2021 20:ed1 DOI:10.1187/cbe.20-12-0285

*Address correspondence to: Erin L. Dolan (eldolan@uga.edu).

(c) 2021 E. L. Dolan. CBE-Life Sciences Education (c) 2021 The American Society for Cell Biology. This article is distributed by The American Society for Cell Biology under license from the author(s). It is available to the public under an Attribution-Noncommercial-Share Alike 3.0 Unported Creative Commons License (http://creativecommons.org/ licenses/by-nc-sa/3.0).

"ASCB®" and "The American Society for Cell Biology $\circledR^{\prime \prime}$ are registered trademarks of The American Society for Cell Biology. 
equitable access by providing fee waivers for authors without the resources to cover publishing costs.

Despite these successes, there is much more work to be done. The overlapping landscapes of publishing, research, and postsecondary education are changing at an ever more rapid pace, spurred by the COVID-19 pandemic and the national reckoning with racial injustice and systemic racism. In many ways, LSE has promoted equity and inclusion. The journal's editorial board has become more diverse in terms of institutional representation, but greater diversity is needed to ensure that the biology education community can benefit from the perspectives, experiences, and contributions of diverse students, educators, and scholars. LSE's special issue on Broadening Participation was an important step in this direction, garnering the most submissions of any themed issue and continuing to attract many readers. The journal has published many essays and articles that directly address issues of diversity, equity, inclusion, and justice. In fact, more than 1200 LSE publications use the word "inclusion," and more than 700 use the word "diversity." Yet many fewer mention equity, and even fewer address justice ( $n=106$ and 37, respectively, at the time this editorial was written). And words simply are not enough. More action is needed. I am so thrilled that Jeff Schinske and Kimberly Tanner will be serving as LSE's new co-Editors-in-Chief, bringing fresh energy and perspectives to publishing in biology education. They both have enduring and impactful track records of centering marginalized and excluded voices that will help ensure that $L S E$ can be both a venue and exemplar for effective and inclusive biology education. I hope LSE readers and authors will join me in supporting them in this important work.

My very best,

Erin L. Dolan

Editor-in-Chief, 2010-2020

CBE_Life Sciences Education 